\title{
A refractory lower extremity variceal ulcer associated with perimedullary arteriovenous fistula
}

Figure 1 Photograph of the patient

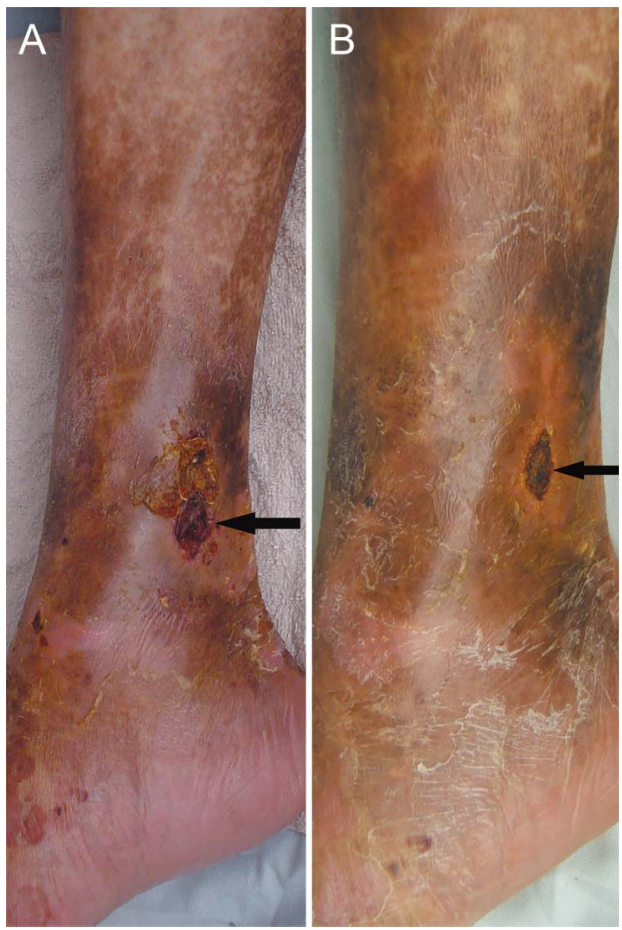

Photograph showing an ulcer with chronic bleeding (arrow) (A) and its alleviation (B).

A 16-year-old male presented with a 3-year history of bilateral lower limb paresthesia and a refractory ulcer next to the swollen right medial malleolus (figure 1A). Lumbar MRI revealed a spinal vascular malformation (figure 2A). Digital subtraction angiography demonstrated a giant perimedullary arteriovenous fistula $(\mathrm{PMAVF})^{1}$ originating from an anterior spinal artery at T10-11, draining into the inferior vena cava, and a few vascular malformations involving the right ankle (figure 2, B-F). Combination surgery and embolization was successfully performed for the PMAVF. Of note, the ulcer resolved without any direct treatment within 7 days (figure 1B).

Feng Ye, MD, Tongyu Wang, MD, Chao You, MD, Shu Jiang, MD, Min He, MD

From the Departments of Neurosurgery, West China Hospital, Sichuan University, China.

Author contributions: All authors were involved in clinical care and investigative workup of the patient. M.H. and F.Y. provided pictures of the patient, drafted and revised the manuscript. T.W. performed the patient follow-up, drafted and revised the manuscript. C.Y. and S.J. were responsible for the study concept and revised the manuscript for intellectual content.

Study funding: No targeted funding reported.

Disclosure: The authors report no disclosures relevant to the manuscript. Go to Neurology.org for full disclosures.

Correspondence to Dr. He: minhe028@126.com

1. Spetzler RF, Detwiler PW, Riina HA, Porter RW. Modified classification of spinal cord vascular lesions. J Neurosurg 2002;96: $145-156$. 
Figure $2 \quad$ MRI and DSA
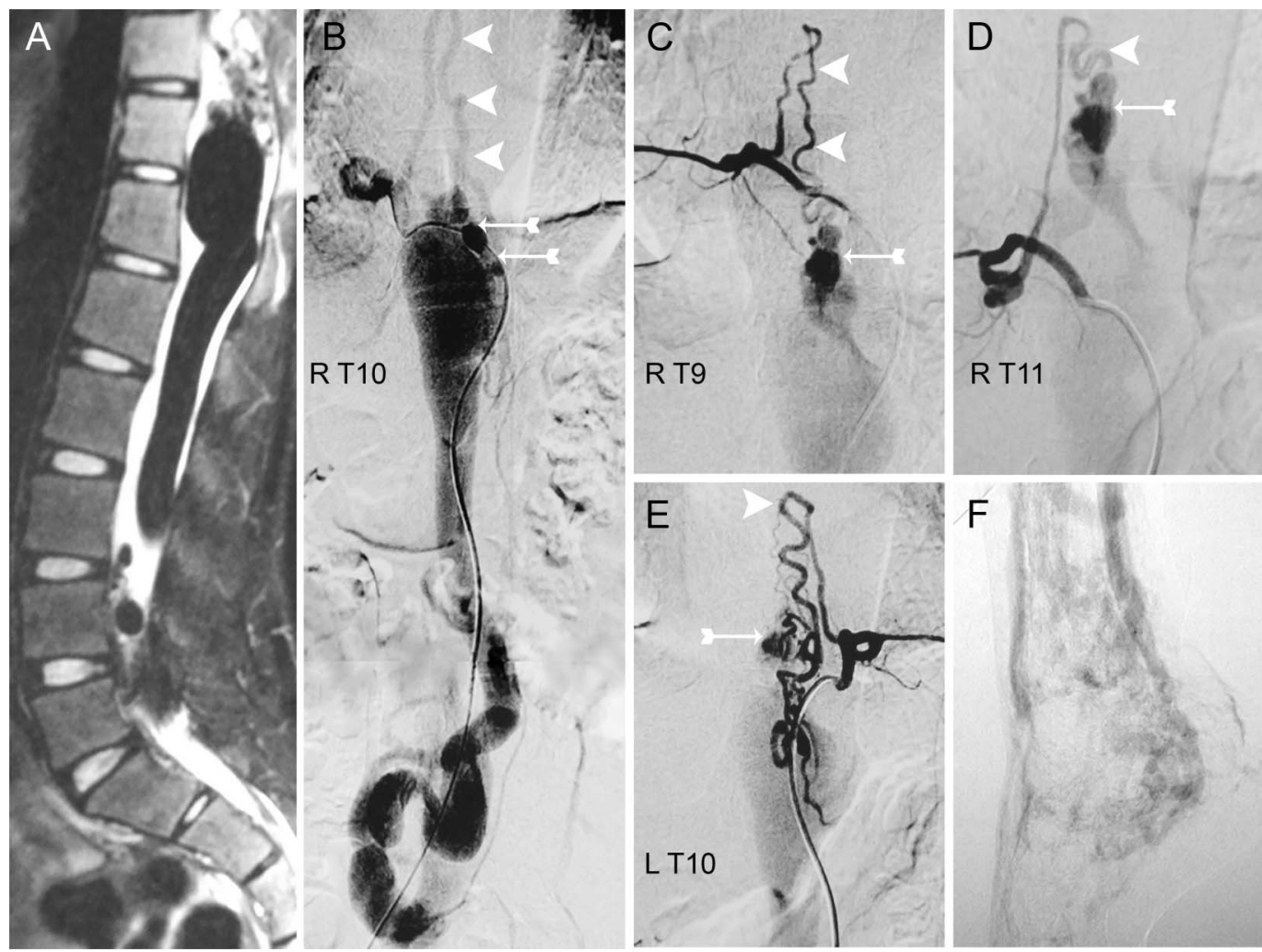

Lumbar MRI (A). Digital subtraction angiography (DSA) demonstrated a fistula (arrow) fed by right T9 (B), T10 (C), T11 (D), and left T10 (E) intercostal arteries via anterior spinal artery (arrowhead). A few small vascular malformations involved the right ankle (F).

\section{Minutes Pack a Punch}

\section{Neurology ${ }^{\circledR}$ Podcasts}

- Interviews with top experts on new clinical research in neurology

- Editorial comments on selected articles

- Convenient-listen during your commute, at your desk, or even at the gym

- On demand-it's there when you want it

- Fun and engaging

- New topic each week

- FREE

Listen now at www.aan.com/podcast 


\section{Neurology}

\section{A refractory lower extremity variceal ulcer associated with perimedullary arteriovenous fistula}

Feng Ye, Tongyu Wang, Chao You, et al.

Neurology 2015;84;1821-1822

DOI 10.1212/WNL.0000000000001527

\section{This information is current as of April 27, 2015}

\section{Updated Information \& Services}

\section{References}

\section{Subspecialty Collections}

\section{Permissions \& Licensing}

\section{Reprints}

including high resolution figures, can be found at: http://n.neurology.org/content/84/17/1821.full

This article cites 1 articles, 0 of which you can access for free at: http://n.neurology.org/content/84/17/1821.full\#ref-list-1

This article, along with others on similar topics, appears in the following collection(s):

All Cerebrovascular disease/Stroke

http://n.neurology.org/cgi/collection/all_cerebrovascular_disease_strok e

All Clinical Neurology

http://n.neurology.org/cgi/collection/all_clinical_neurology

All Neurotology

http://n.neurology.org/cgi/collection/all_neurotology

All Spinal Cord

http://n.neurology.org/cgi/collection/all_spinal_cord

Arteriovenous malformation

http://n.neurology.org/cgi/collection/arteriovenous_malformation

MRI

http://n.neurology.org/cgi/collection/mri

Information about reproducing this article in parts (figures,tables) or in its entirety can be found online at:

http://www.neurology.org/about/about_the_journal\#permissions

Information about ordering reprints can be found online:

http://n.neurology.org/subscribers/advertise

Neurology ${ }^{\circledR}$ is the official journal of the American Academy of Neurology. Published continuously since 1951, it is now a weekly with 48 issues per year. Copyright @ 2015 American Academy of Neurology. All rights reserved. Print ISSN: 0028-3878. Online ISSN: 1526-632X.

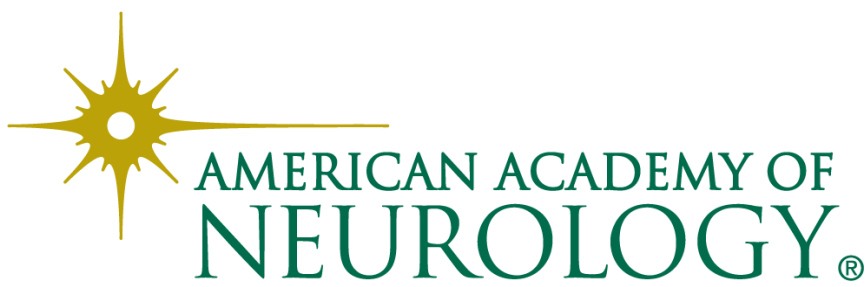

